\title{
Aksi Bela Islam: islamic clicktivism and the new authority of religious propaganda in the millennial age in Indonesia
}

\author{
Muzayyin Ahyar \\ Institut Agama Islam Negeri (IAIN) Samarinda (Samarinda State Institute of \\ Islamic Studies) Indonesia \\ E-mail:muz.ahyar@gmail.com
}

\author{
Alfitri \\ Institut Agama Islam Negeri (IAIN) Samarinda (Samarinda State Institute of Islamic Studies) \\ Indonesia \\ E-mail:al.alfitri@gmail.com
}

DOI : 10.18326/ijims.v9i1. 1-29

\begin{abstract}
The great Islamic mass rally which well known as "Aksi Bela Islam (Defending Islam action) 212" in Indonesia has always been claimed as the triumph of Islamic activism. This action continue to be voiced through social media such as Facebook, Twitter, Instagram, and so forth with the jargon " 212 spirit ". The voluminous actions of "Aksi Bela Islam 212" sound like an authoritative propaganda jargon which are exhaled to spread the Islamic identity through the internet. Along with the proliferation of online Islamic activism, some major questions emerge about: (1) whether online religious discourse is an authoritative source that gives Muslim society an authority in religious propaganda; (2) to what extent the proliferation of online Islamic activism has shaped the new
\end{abstract}


Islamic propaganda authority? The objective of this article is to examine the discourse of Islamic activism in the online public sphere which makes the internet and online social media as a new vehicle in the transformation of traditional-modern Islamic propaganda authority for technologically literate generation. The article highlights some transformations of traditional religious propaganda authority to the new one which appropriated with the technological advancement. Using political sociology approach, this article will maps an Islamic online activism, which is termed as Islamic clicktivism, and its relation to the religious propaganda authority. The finding of this article reveals that Islamic clicktivism can be an authoritative method in shaping religious and political discourses. Finally, this article argues that Islamic social movement in the millennial age - especially in the post 212 movement - has consistency to play a role in political contestation through the Islamic clicktivism.

Gerakan aksi masal Islam yang dikenal dengan Aksi Bela Islam di Indonesia selalu diklaim sebagai kemenangan aktivisme Islam. Menyusul Aksi Bela Islam dalam ranah gerakan sosial, wacana serupa juga disuarakan melalui gerakan aktivisme secara daring yang disebarkan melalui berbagai media social seperti Facebook, Twitter dan Istagram dengan jargo "spirit 212". Aksi berjilid-jilid dari Aksi Bela Islam ini terdengan seakan menjadi jargon propaganda otoritatif yang dihembuskan untuk menyebarkan identitas Islam melalui internet. Seiring dengan fenomena proliferasi gerakan-gerakan Islam daring tersebut, beberapa pertanyaan muncul: pertama, apakah diskursus keagamaan daring menjadi sumber otoritatif yang memberikan otoritas kepada masyarkat Muslim dalam hal propaganda agama? Kedua, sejauh mana proliferasi aktivisme Islam daring membentuk otoritas propaganda keagamaan baru? Sasaran dari artikel ini adalah menguji wacana aktivisme Islam di ruang public daring yang menjadikan internet dan media social daring sebagai kendaraan baru dalam transformasi otoritas propaganda keagamaan dari tradisional ke modern bagi kalangan melek milenial yang melek teknologi. Artikel ini menyoroti beberapa trasnformasi propaganda keagamaan tradisional menuju modern yang disesuaikan dengan perkembangan teknologi. Dengan menggunakan pendekatan sosiologipolitik, artikel ini memetakan aktivisme Islam daring, yang diistilahkan dengan Islamic clicktivism, dan hubungannnya dengan otoritas propaganda keagamaan. Temuan artikel ini menunjukkan bahwa kliktifisme Islam dapat 
menjadi metode otoritatif dalam membentuk wacana keagamaan dan politik sekaligus. Pada akhirnya artikel ini menegaskan bahwa gerakan social Islam di era milenial - khususnya pasca gerakan 212 -secara konsisten mengambil peran dalam kontestasi politik identitas dengan menggunakan kliktifisme Islam.

Keywords: Aksi Bela Islam; Religious authority; Clicktivism; Populism

\section{Introduction}

The statement of former Jakarta governor Basuki Tjahaya Purnama (a.k.a. Ahok) has triggered a voluminious defending Islam actions in Indonesia. The actions began in late 2016 and they continued until 2018. This rage caused by Ahok's speech during a working visit and the socialization of the provincial government program to Pramuka Island in Kepulauan Seribu Jakarta on 27 September 2016. The speech became a heated discussion soon after Buni Yani, a youtuber, uploaded the video by commenting that the video has insulted the Quran, the Holy Book of Muslims. ${ }^{1}$ The short video is then spreaded by hundreds of netizens in various social media or online short message senders such as Facebook, Twitter, Instagram, WhatsApp, Line, and so forth. This video then successfully triggered angers among the Muslim community with the presence of rage postings: either in the form of pictures, photos, statuses, or brief comments on various social media platforms. A series of demonstrations followed the post-dissemination of Ahok's video. ${ }^{2}$ In midOctober 2016, a group of people gathered in front of Jakarta's city hall to protest Ahok's statement which insulted Muslims. The demonstration

${ }^{1}$ Ahmad Najib Burhani, "Aksi Bela Islam: Konservatisme dan Fragmentasi Otoritas Keagamaan,” Maarif 11, No. 2 (December 2016), 17-18

${ }^{2}$ Ari Ganjar Herdiansah, et.al., "The Islam Defence Action: A Challenge of Islamic Movement to Democratic Transition in the Post 2014 Indonesia," Wacana 20, No. 2 (2017), $62-65$. 
has continued on November 4, 2016, December 2, 2016, February 21, 2017, March 3, 2017, and May 5, 2017 with a larger mass.

Looking deeply at the process of formation of this movement of Aksi Bela Islam, there is a pattern that is depicted in the action as a social movement. The pattern begins with an action of propaganda through the sails of technological devices, which is followed by supportive comments on the propaganda, and ends in mass mobilization for a real social movement for a purpose. This action is claimed to be attended by millions of people from all over Indonesia. The participants also claim that their coming to the capital city is voluntarily to voice one thing, namely justice for Muslims and Islam. Nevertheless, amidst the protesters in Jakarta, the action did not receive an official support from two mainstream Islamic organizations in Indonesia; Muhammadiyah and Nahdhatul Ulama. These two mainstream Islamic organizations seem to lose their authority as an institution that shapes Muslim religious attitudes and actions during the Ahok case in Indonesia. The Islamic Defense Action also indicates that there is a growing trend of new authorities in Indonesia which is capable of directing the actions of Indonesian Muslim community in addition to the Muhammadiyah and NU.

Some studies suggest that the Islamic Defense Action is closely related to the political moment. Greg Fealey considers that the incident of Islamic Defense Action in the Ahok case is a setback for political diversity in Indonesia. The Islamic Defense action is present to revive the battle of primordialism and the identity between the "native" and "non-native" Indonesians to promote their privileged position among Muslims as the majority and is regarded to have the authority of Indonesian politics. Moreover, the Islamic Defense Action was carried out prior to the democratic election moment for the Governor of DKI Jakarta. Ahok's incident certainly has serious consequences for Indonesian society; 
Indonesia must rethink its claims as a moderate Muslim democracy. ${ }^{3}$ Meanwhile, Merlyna Lim argues that amid the freedom of information, all people can easily argue. Assisted with technological developments, the opinions expressed will be easily spread to other communities so as to trigger differences of opinion. This disagreement resulted in a strong polarization resulting in a threat to democracy by bringing the patterns of the tribal paradigm. Both camps (Ahok's supporters and Ahok's Opponents) make a clear demarcation between anti-Pancasila and anti-Islam, which in Lim's terms is called an algorithmic enclave. This algorithmic enclave is an ongoing trend during identity battles occurring in online social media because people easily mobilize cyberspace by building deconstructive opinions for their political identity opponents. ${ }^{4}$ Fealey's and Lim's studies emphasize a similar thesis; namely the strengthening of post-democratic political identity contestation in Indonesia which is sometimes still colored by emotional outbursts by each identity that fights with carrying primordial propaganda. However, Lim simply concentrates on studying online social movements that carry different characteristics and propaganda tools from social movements in the early days of reform, while Fealey focuses on mass movements capable of being mobilized with religious propaganda. Nevertheless, these two studies may lead to a new question; what kind of religious authority can play the online and offline identity fight? How such authority is able to be present in the midst of two mainstream Islamic organizations: Muhammadiyah and NU? Who are the new actors appearing in the midst of the movement claimed as the super-peaceful and democratic Islamic social movement? What is the

${ }^{3}$ Greg Fealy, "Bigger than Ahok: Explaining the 2 December Mass Rally," Indonesia at Melbourne, last modified December 7, 2016, accessed March 29, 2017, http:// indonesiaatmelbourne.unimelb.edu.au/bigger-than-ahok-explaining-jakartas-2-decembermass-rally/.

${ }^{4}$ Merlyna Lim, "Freedom to Hate: Social Media, Algorithmic Enclaves, and the Rise of Tribal Nationalism in Indonesia," Critical Asian Studies 49, no. 3 (July 3, 2017): 411-427. 
future of these voluminous Islamic defense actions when they meet the political context? Those questions are a fraction of the focus that will be discussed in this article; which is related to the dynamics of religious authority amid the development of democracy and technological progress in this millennial century.

\section{Social movement, religious authority and propaganda}

The term authority has emerged since the beginning of the social sciences discussion. Various definitions in the classical era try to dissect what and how authority works in a social system. ${ }^{5}$ The Weberian classic definition of authority is attached to something related to domination (herrschaft). Something dominates over something else, individuals dominate over other individuals, and groups over other groups. This dominating ability is then divided by Weber into three forms; charismatic, traditional and legitimate authority. The simplification of this authority will be more easily understood when it comes to political studies and power. In its development, authority is always juxtaposed with power, meaning authority is something inherent with power. Authority is the right to act to make a rule, while power is understood as the ability to force in obeying the rule. In essence, authority has an element of rights, values and norms that underlie someone to do what he has to do. ${ }^{6}$

In the landscape of Islamic studies, issues related to authority are still attached to the concept of tripartite authority proposed by Max Weber. They are: first, a charismatic authority that covers matters relating to familial and religious. Second, a traditional authority which is present in the medieval era, with the characters of patriarchal society, patrimonialism and feudalism. Third, a legal authority which comes

\footnotetext{
${ }^{5}$ Max Weber, On Charisma and Institution Building, Chicago: University of Chicago Press, 1968.

${ }^{6}$ Angela Cheater, The Anthropology of Power, London: Routledge, 2003.
} 
after the political revolution and the social system in the middle ages. This legal authority gave birth to a product called the state bureaucracy, which seeks to bridge the interests of society and the interests of the authorities. Legal authority is present when law developed in modern countries since the mid-19th century along with the democratization process in several European countries. According to Weber, these three forms of authority are a semi-hierarchical passage. A state will move from charismatic authority to powerful religious institutions, then to a feudal and patrimonial society resulting from a noble rebellion against the religious institutions. Then, the society will move toward the legal authority acquired by the democratization and the public's resistance to the feudal and patrimonial social system. ${ }^{7}$

Nevertheless, the tripartite authority cannot actually go hierarchically. In countries where the spirit of state management is based on majority religious values, there is a duality of attitudes between charismatic authorities and legal authorities. Sometimes the two authorities go hand in hand, and sometimes also led the condition of one of the authorities vis-a-vis other authorities. Even the modern social, economic, political and legal products, still according to Weber, are often driven by religious zeal. Supporting this thesis, Weber attempted to trace with the question "why developments in Western European countries are more advanced and financially ripe ahead of the neighboring states of Eastern Europe?" Weber argues that progress in western European countries is due to bureaucracy and good state administration and other private sectors. This good bureaucracy and administration is recognized as weber is the product of the spirit of societal capitalism pursuing the acceleration of production, in which the acceleration of production forces one to be followed by clear administration and bureaucracy for the validity

\footnotetext{
${ }^{7}$ Weber, On Charisma and Institution Building.
} 
of the calculation of capitalistic products. Then, how can the soul of Western European society's capitalism be too strong? Weber believes that capitalism is driven by Protestant ethics that reject world misery and poverty (as God's absolute destiny) as any other Catholic Church dogma. The meeting point between capitalism and Protestantism, according to Weber, is the spirit of liberation of scripture interpretation of human behavior in the World, especially in the field of respect for human capital. The practice of indulgences abused by the Catholic Church authorities encouraged Marthin Luther to reinterpret the indulgences. Salvation does not stick to Church approval alone; men must seek salvation from a different path. Protestants should look for other signs that show that they are safe. The result, the worldly order became one of the signs and measures of salvation. The more capital one has, the greater opportunity one gain to help others and bring people to safety. This Protestant ethic developed after the reform of Church authorities in Western Europe. ${ }^{8}$

Religious authority in Islam is certainly different from the hierarchical Catholic Church authority. Therefore, the function of the mosque does not have strong authority as in the church tradition of Christians. The authoritative source of Muslim society is very diverse and not monopolized by mosque Imams, nor hierarchical power derived from the holy land (Mecca). In Indonesia, Islamic religious authority is in some institutions. As the largest Islamic mass organization, Nahdhatul Ulama (NU) and Muhammadiyah are authoritative institutions in shaping the religious acts of Muslim society in Indonesia. At the State level, the Indonesian Council of Ulama is present as a reflection of the state on the authority of the decisions of Islamic religious affairs through its fatwa. In addition, the Ministry of Religious Affairs takes the position of authority in the field of "administration of religions". In smaller scope, Islamic religious

\footnotetext{
${ }^{8}$ Max Weber, The Protestant Ethic and the Spirit of Capitalism, New York: Scribner, 1958.
} 
authorities are grasped by institutions and some other non-mainstream individuals such as Sufi traditions, Political Islam, and informal-local Islamic leaders spread across many regions of Indonesia. ${ }^{9}$

Social movement becomes an interesting theory to dissect how an action works for a particular purpose. The Islamic Defense Action has considerable relevance when viewed in the frames of social movements. Social movement is one of the discussions in political studies. In contemporary discussions, social movements show how society demands a change by taking action in mobilized masses. The unique characteristic of social movements is that their movement is guided in their intention and strategy (purposively and strategically), by the cross-community that participates in the movement. In addition, social movements appear massively outside the established political or institutional channels within a country. ${ }^{10}$ Social movement is closely related to a shared ideal and responds to a political power. Sidney Tarrow presents three big puzzles related to social movements and sociopolitical conditions: first, what conditions bring the power of the movement can emerge; Second, how the dynamics of movement that can perpetuate the power of the movement; third, what sorts of social outcomes or the effects and impacts of such social movements. The three puzzles brought Tarrow to several theories for further exploration. Tarrow insisted that one of the key answers to the puzzle was political opportunity (a political opportunity, a social movement increased when it gained the support of resources and successfully mobilized the resource.) When the political opportunity structure was open, social movement actors used elite support in the system. This becomes one of the variables driving the progress of the social movement to form a force. The structure of political opportunity

\footnotetext{
${ }^{9}$ Azyumardi Azra, Kees van Dijk, and Nico J. G. Kaptein, Varieties of Religious Authority: Changes and Challenges in 20th Century Indonesian Islam, Singapore: Institute of Southeast Asian Studies, 2010.

${ }^{10}$ Hank Johnston, What Is a Social Movement? UK: John Wiley \& Sons, 2014.
} 
will help a study of social movements by explaining how the actors of the movement merge in a collective action and network between one social group with another social group to voice the purpose of action. This is called by Tarrow as a seizing and making opportunity, using and forming political opportunities through social movement actors. ${ }^{11}$ Peter Eisinger sees and compares this political opportunity to two political conditions: closed and open condition. Eisinger wants to know if the protests and the emergence of various social movements are caused by political conditions that are under pressure or in openness? Eisinger concluded that just as state institutions are open, protests from the social movement are increasing. ${ }^{12}$

In a movement, mobilization becomes a way to add strength, at least in mass quantity. The development of social movements is also largely determined by how large and powerful the resources are and whether the resources are mobilized appropriately. Tarrow explains that for the mobilization process and the mobilization object are used appropriately, there are three important elements that must be run symbiotically in social movements, namely formal organization, mobilizing structure, and organization of collective action. Tarrow says actors of mobilization structures in a movement must be internalized in two other ways controlled by high-level leaders, ${ }^{13}$ in other terms, those who have the legitimacy of power or charismatic leaders.

In launching an action, there needs to be propaganda to awaken the soul of the collectivism of other societies in order to agree with the discourses echoed in the social movement. Propaganda becomes an important part in spreading a massive discourse to achieve a goal. Theoretically,

${ }^{11}$ Sidney Tarrow, Power in Movement: Social Movements and Contentious Politics, New York: Cambridge University Press, 1998.

12 Peter K. Eisinger, "The Conditions of Protest Behavior in American Cities," The American Political Science Review, Vol. 67. No.1. (1972).

13 Sidney Tarrow, Power and Movement..., 136. 
propaganda studies evolve from the historiography narrative of dictatorial government to the sciences of mass communication discussions that are often defined as attempts to shape influence, change, and control the attitudes and opinions of a person or group for a particular purpose or to be brought in a particular direction. Propaganda as a political strategy must have been used long before the modern era. However, the development of propaganda as a scientific study began to be heavily discussed after World War I. Indeed, the 1990s have been called "the century propaganda" and "the age of propaganda". When the world war raged, all parties involved in the onslaught of war tactics and tactics to weaken the opponent. An ongoing study of hate propaganda is discussed when it is considered one of the most effective tactics to strengthen defense and weaken the opposing side. ${ }^{14}$

\section{Paradigm turn: from offline to online activism}

In the past, propaganda messages were always present in the pages of newspapers, free flyers taped to the walls of city buildings. Propaganda is present as a representation of a political ideology it embraces an essential trinity: rhetoric, myth and symbolism. Rhetoric, symbolism and myth are a trinity that relates to each other in running propaganda programs. Good rhetoric becomes the beginning of public interest in digesting an idea. Therefore, world leaders in the era of world war are always known for their rhetorical ability delivered through state speeches; Adolf Hitler, Winston Churchill, Harry S, Turman, Mussolini, Josef Stalin, Franklin D Roosevelt. Even Sukarno of Indonesia has always been known for his fiery speech. Meanwhile symbols are another component in this trinity.

${ }^{14}$ Stanley B. Cunningham, The Idea of Propaganda: A Reconstruction, USA: Greenwood Publishing Group, 2002; Edward Bernays, Propaganda, New York: Ig Publishing, 2005; see Nicholas J. O'Shaughnessy, Politics and Propaganda: Weapons of Mass Seduction UK: Manchester University Press, 2004. 
The symbol in this case is not merely a visualized image; it can be a person, photo, wise quotes, or anything that can be seen to represent the abstraction of an object, idea, and purposes. Symbols become a universal language that can be understood even by different cultures. Symbols can also last forever; in which the old symbols are able to be reproduced for the sake of new ideas and ideas that were born later. The last trinity component in propaganda is myth. Myth does not mean stories related to ancient cultural traditions or mythological tales. Myth here means a short message that is always told over and over again to achieve a certain goal. In this case, the stereotype is myth in propaganda. ${ }^{15}$

In other fields, religious leaders take on the role of propagandists of religious values. Indonesia as a country with a majority Muslim population has thousands of activities that seek to propagate Islam as a way of life. This propaganda activity is pursued by the various ways and unique character of each group. In two major Islamic organizations mainstream in Indonesia; Muhammadiyah and NU are representing the Sunnism. As the established Islamic mass organization, Muhammadiyah and NU nowadays are the authoritative institution in propagating the ahlussunnah wal jamāah practices in Indonesia ${ }^{16}$

The rapid development of the world of technology and information make propaganda adapt the context of the development. Post-World War II, propaganda is not merely a government monopoly to give confidence to its people against the enemies of the state. Propaganda appears more intense by small groups with other group ideological opponents. Moreover, with the development of the mass media industry has spawned a new style of propaganda with tools, ways, and models tailored to the context of technological developments. In the Reformation era in Indonesia,

\footnotetext{
${ }^{15}$ O'Shaughnessy, Politics and Propaganda.

${ }^{16}$ Asfa Widiyanto, Religious Authority and the Prospects for Religious Pluralism in Indonesia: The Role of Traditionalist Muslim Scholars, Berlin: LIT Verlag Münster, 2016.
} 
propaganda is also often done not only by the government, but also by social movements that echo multiple identities; be it a primordial identity of ethnicity, religion, political ideology and profession.

Technological developments have influenced many social and political dimensions. In the field of information, technological developments simultaneously arouse the spirit of massive information dissemination. In the mid-19th century, various information and political activities were spread through newspapers printed on the press of the industrial revolution machine, after which technology grew rapidly until the media was able to visualize the information in its entirety; namely television. However, some of the information media is certainly not accessible to everyone because the price is not affordable, only among investors who can act through the media information. The limitations of the media in this political arena are judged to be contrary to the democracy values that allow anyone to actively participate in political activities and voice the aspirations of the government.

The 1980s became the beginning for the revival of more friendly and affordable information media for democratic societies. Here comes the Internet as a new information medium. Over the course of the past decade, the internet has penetrated into the broader layers of society. The range of network-based services is booming like BITNET (because it's time to network) and CSNET (Computer Science Network) that provides e-mail services. Along with the development of services gathered in cyberspace, then born a new community that may not necessarily meet in the real world, but intensely communicate in cyberspace; that is virtual communities. ${ }^{17}$ Some changes in information and technology will give birth to new nuances in propaganda programs and social movements.

${ }^{17}$ Howard Rheingold, The Virtual Community: Homesteading on the Electronic Frontier, London: MIT Press, 2000. 
Activists should move on to new propaganda styles with less risk; be it social or financial risks of financial risk. By switching to the online paradigm, propaganda is easier to do because it is based on the internet. The Internet is a device that is rated convivial; cheaper in terms of financing and more formally distributed. ${ }^{18}$

The shift of the paradigm of activists to propaganda instantly through technology tools also changed the authoritative source in propaganda. In previous eras - especially in authoritarian regimes prior to the reformation era in Indonesia - the state was an authoritative source for social campaigning. The state is the only one that can legitimize whether propaganda is good or bad to do. In the case of Indonesia, the Ministry of Information became the mouthpiece of the government in propaganda. What is reported by the media in Indonesia, must have been approved by the Ministry of Information and legitimately spread by word of mouth by other communities. Not just news, the Ministry of Information must foster a variety of theatrical art to fit the vision and mission of the New Order government and become one of the government's propaganda mouthpieces. Government propaganda is voiced by various arts languages such as ludruk, Longser wayang kulit or leather puppets, Ondel-Ondel on the island of Java, and Mamanda in Kalimantan. Various art groups are directly guided by the Directorate of People's Information, Ministry of Information. Since the Information Department was abolished by the government of President Abdurrahman Wahid, these folk art groups has been fading followed by the fading of the government's propaganda funnel through some cultural arts. ${ }^{19}$

After the fall of the New Order regime, the social movements of the

${ }^{18}$ Merlyna Lim, “@rchipelago Online: The Internet and Political Activism in Indonesia”, Ph.D Thesis (Twente, 2005).

${ }^{19}$ Mahdiduri Mahdiduri, Ubrug; Tontonan dan Tuntunan, Dinas Pendidikan Propinsi Banten \& Lembaga Keilmuan dan Kebudayaan Nimus Institut, 2010. 
people increased significantly. Democracy brings a fresh breeze to the variety of identities to appear in public, the demonstration becomes a frequent political phenomenon. Demonstrations have an important role in public prosecution of political elites. On a large scale, this demonstration can culminate into a social movement with mass mobilization capable of mobilizing from various parts of Indonesia. According to Lim, social media has played an important role in facilitating successful mass mobilization through what she calls as social media activism. ${ }^{20}$ Islamic Defense Action is one of the big actions that claimed to bring millions of people from various regions. The significant question is why are they willing and able to be present in the mass movement in Jakarta? Meanwhile the cost to attend the action is certainly not small for those who come from outside Jakarta, especially those coming from outside the island of Java. In the case of voluminous Islamic Defense Action, the participants of the action came from various regions of Indonesia. data for this article is collected from direct interviews with some of the participants of the action, and the process of movement is then categorized with various variants; ranging from social media campaigns, simultaneous movements in various regions, to mass mobilization centered on one point namely the National Monument in Jakarta.

In the early action of October 14, 2016, the protest movement against Ahok's speech was only done in the city hall area of DKI Jakarta. In this first action, a single command is on the Islamic Defenders Front (FPI), headed by a figure who is currently claimed to be the high priest of the Muslims; Habib Rizieq Syihab. In their demands, the masses want the legal process to run quickly against Ahok who considered blaspheming Islam. A few weeks after the first action, the process of settling the cases

\footnotetext{
${ }^{20}$ Merlyna Lim, "Many Clicks but Little Sticks: Social Media Activism in Indonesia," Journal of Contemporary Asia 43, No. 4 (2013): 636-657.
} 
of blasphemy is considered to be running slowly. So the discourse about the legal process re-voiced through various social media. As a result, the message of action discourse widespread that led to follow-up action on November 4, 2016. In this second action, mass movement spread in various regions in Indonesia; Medan, Solo, Samarinda, Balikpapan, other cities. The next action was centered in Jakarta involving millions of people from all over Indonesia. Participants come from various backgrounds, ages and professions. In organizing the masses, supporters of Islamic Defense Movement throughout the cities form sporadic organizations which started from various gathering like majlis taklim, campus organization and other religious associations. Their espousal in the Islamic Defense Movement make themselves join the group. They also create online social media groups to facilitate the arrangement of departure to Jakarta with a variety of funding sources; be it self-financing and sponsorship. Several supporters of the Islamic Defense Movement acknowledged that they were voluntary and without compulsion to pay for attending the national movement, even among them had to set aside money for snack because they are still active students in several public and private universities. ${ }^{21}$

Community participation from various regions cannot be separated from the role of online social media as a strategy of mass mobilization and dissemination of discourse. ${ }^{22}$ The key actors of the Islamic Defense Action succeed in influencing the masses through short messages, memes and propaganda images by relying on the internet. In Indonesia, the use of the Internet as a medium of political activism has grown since

\footnotetext{
${ }^{21}$ Interview with some Islamic Defense Movement supporters in several cities; Samarinda, Balikpapan and Solo

${ }^{22} \mathrm{Lim}$, however, noted that not all social media activism successfully gained support from the public; see her case studies on succesfull (KPK and Prita Case) and unsucessfull social media activisms (Lapindo and Ahmadiyya Case) in Lim, "Many Clicks," 640-652.
} 
the 1990s. For the first time, mailing lists from e-mail providers were created to mobilize the masses who wanted to reform the power of the New Order regime. Therefore, the reform of 1998 cannot be separated from the discussion of the development of the internet. In the field of religious social, in the case of Laskar Jihad, the internet also managed to mobilize the religious army to go into the conflict field in Ambon, Indonesia, about dozens of people successfully mobilized via the internet available in internet network stalls (Indonesian:Warnet). In addition, the internet makes it easy for Laskar Jihad main actors to gain access from al-Qaeda and Jama'ah Islamiyah (JI), a network of radically developed early groups in the Middle East. Although the cooperation was rejected by Ja'far Umar Thalib as laskar leader, but in this case has proved that the internet is able to facilitate activists to network and create new public spaces in carrying out their political intentions. ${ }^{23}$

Why are they willing to volunteer to go and follow the Islamic Defense Action? Indeed, one of the uniqueness of the religious movement is its volunteeristic stance. However, when viewed from the theory of social movements that they still feel as a militant movement that has some basic things that should be nurtured (basic properties of movements). Basic properties of movement are usually collective challenges that make them interrupt, obstructing and opposing together, aimed at the activities of other groups that do not have ideologies like them, or attitudes that are considered contrary to Islam. Another fundamental is the common purpose, which is used to achieve the interests of the group. The common goal is the reason for mass networks taking risks to act collectively in the name of group solidarity, that is, a sense of equal struggle within a community. In addition, a militant movement has a collective action defense. They must be able to defend the group from various challenges

\footnotetext{
${ }^{23}$ Lim, “@rchipelago Online."
} 
by taking advantage of whatever opportunities are present around them. ${ }^{24}$ The Islamic Defense Action illustrates how social movements have dynamic interplay with the movement of online activism in the form of ideological discourse propaganda spread through online social media.

\section{New trend, new strategy and new actors}

Some Islamic social movements become interesting to study because of the dialectics between the minds of Islamic and secular countries. Muslim countries are always faced with a dilemmatic attitude; between establishing religious norms on the one hand, and applying modern and secular values in the frame of the nation-state on the other. ${ }^{25}$ Moreover, after the Arab Spring that almost hit all of the Arab countries, Indonesia and Turkey have become models of how the mind of religious state can fight with the mind of secular state without serious conflict. In other cases, Morocco became a much-watched country because of the massive process of the protest movement that brought Morocco into the constitutional reform, but without experiencing the fall of the regime and the victims in large numbers. ${ }^{26}$ All the social movements that occurred in the millennial have different characteristics from the earlier social movements. The only difference lies in the strategies used by activists, namely by using the internet. This pattern of Internet links and social

\footnotetext{
${ }^{24}$ Sidney Tarrow, Power in Movement,. 3-5.

${ }^{25}$ More discussions about this issue can be read from some following studies Mark Juergensmeyer, The New Cold War? Religious Nationalism Confronts the Secular State, California: University of California Press, 1993; Benjamin Barber, Jihad us. McWorld: Terrorism's Challenge to Democracy, New York: Random House Publishing Group, 2010; John L. Esposito and John Obert Voll, Islam and Democracy, USA: Oxford University Press, 1996; Asep Muhammad Iqbal and Zulkifli Zulkifli, "Islamic Fundamentalism, Nation- State and Global Citizenship: The Case of Hizb Ut-Tahrir," Indonesian Journal of Islam and Muslim Societies 6, no. 1 (June 1, 2016): 35-61; John Keane, Global Civil Society? (UK: Cambridge University Press, 2003).

${ }^{26}$ Ibnu Burdah, "Morocco Protest Movements in the Post-Constitutional Reform," Indonesian Journal of Islam and Muslim Societies 7, no. 2 (December 1, 2017): 201-219.
} 
movements can be divided into two types of internet-based activism and internet-supported activism. Internet-supported activism is an activism that uses the internet as a supporting medium of a movement. The existence of the Internet does not bring great influence in the pattern of activism like this. Meanwhile internet-based activism is an activism that really rests its movement on internet media such as "bomb like and email", online petitions and protest websites. ${ }^{27}$ These two typologies of online activism can be a massive movement if the voiced action relates to the greatly managed country narrative. ${ }^{28}$ The dynamic interplay between activism and online activism has become a trend that occurs almost in every sphere of activism. Micah White calls this trend of activism the term "clicktivism", the acronym between the word "click" as a virtual activity, and "activism" as a political movement and identity. The term began to be widely used after popularization by Micah White when he made the Occupy Wall Street (OWS) protest movement in mid-2011 in the United States. This movement is increasingly done by the community thanks to the ease of accessing technology. Despite being an effective and efficient trend in voting for the aspirations of the public, White realizes that clicktivism actually hampers the "leftist" fighting power as the front guard against the hegemony of political elites. Clicktivism only seeks to quantify empathy for a discourse without emphasizing real participation. Activists seek to mobilize votes online to gain support from the global community, so success can be measured by tracking how much "click" or online support is received from a discourse published through online social media. ${ }^{29}$

27 Jeroen Van Laer and Peter Van Aelst, "Internet and Social Movement Action Repertoires: Opportunities and Limitations," Information, Communication $\mathcal{E}$ Society 13, no. 8 (December 2010): 1146-1171.

${ }^{28}$ Muzayyin Ahyar, "Islamic Clicktivism: Internet, Democracy and Contemporary Islamist Activism in Surakarta," Studia Islamika vol 24, no. 3 (December 31, 2017): 435-468.

${ }^{29}$ Micah White, The End of Protest: A New Playbook for Revolution, Canada: Knopf Canada, 
In Indonesia, this model of clicktivism is also used by some Islamic movements in voicing religious identity. The Islamic Defense Action always throws religion (Islam) versus state discourse online in various social media. In fact, the voiced discourse is laden with the ideology of Islamism that wants Islam to be a comprehensive way of life that include in the socio-economic-political-culture and not just a ritual of worship. However, the ideology of Islamism present in Indonesia has transformed into post-Islamism, the critical discourse that arises in responding to Islamism which is considered too conservative and not contextual with the development of the times. Post-Islamism describes Islamism that adapts to modern political styles, democracy and human rights. The trends of the phenomenon of Islamism towards post-Islamism have occurred in various Muslim worlds - including Indonesia - in the form of political parties, mass organizations, interest groups and even social movements. ${ }^{30}$ These discourses are propagated through social media by multiple support accounts in various forms; hash tag, memes, photos and videos. Social media accounts which are mostly used by the crowds are: Instagram, Facebook, and Twitter which each has its own peculiarities in terms of application features and community users. On Facebook's social media, the discourse is voiced through dozens of pages titled "Aksi Bela Islam". Most followers of the dozens of pages are Islamic defense action with user@aksibelaislamalquran with 21,000 more followers and like. This facebook page began to voice propaganda related to Islamic defend on November 6, 2016 by posting status from one Indonesia's leading preacher.

Furthermore, this Facebook page has always been active in voicing Islamic propaganda through the status and pictures regarding the 2016.

30 Asef Bayat, Post-Islamism: The Changing Faces of Political Islam, New York: Oxford University Press, 2013. 
government policy, social conditions, political activities and various other things that are considered "detrimental to Islam". Twitter which is the pioneer of social media of using hash tag has the privilege in spreading propaganda by looking at the top trend of the word being discussed in "tweet" by the "tweeple". The current Twitter app is less favored by young people because they see it has many shortcomings such as character limits written for a status or photo caption. Currently, netizens prefer Instagram because it has a more convenient and friendly feature used in campaigning for agenda. These three online social media became a promising forum for Islamic propagandists in Indonesia in launching religious propaganda because it is very potential to be consumed by cyber activists. This statement is corroborated by the results of research conducted by We Are Social claiming that Indonesia - a country with the 3rd largest social media user after Saudi Arabia and India, ranked 4th in the world of the people who spend time with the internet and ranked 1st in Southeast Asia. ${ }^{31}$ Since hash tag became applicable in social media Facebook, traces of discussion about the Action of Islamic Defense and the discourse of Islamism is easy to trace. The Islamic activists voiced their propaganda by hunting down into a trending topic of discussion on an online social media. They campaign for something by emblazoning a mark at the beginning of the word as a message that is easily grouped in cyberspace networks. Islamic Defense Action has a uniform hash tag written \#aksibelaislam, another hash tag that becomes Islamic propaganda is \# spirit212. The propaganda is spelled out by personal and group-created accounts. In early 2018, Muslim Cyber Army was heavily discussed because it is considered to be a source of negative propaganda that always spread the sentiments of tribe, religion, races, and interclass

31 "Digital in 2018: World's Internet Users Pass the 4 Billion Mark - We Are Social UK," accessed June 22, 2018, https://wearesocial.com/uk/blog/2018/01/global-digitalreport-2018. 
(SARA). The Muslim Cyber Army is one of the social phenomena of how propaganda is rolling in society, which is capable of generating a new authority in introducing ideas, groups and actors who are considered more authoritative in giving an understanding of Islam.

Table1. hashtag of Islamist propaganda in online Social media

\begin{tabular}{|c|c|c|}
\hline $\begin{array}{l}\text { SOCIAL } \\
\text { MEDIA }\end{array}$ & $\begin{array}{l}\text { PROPAGANDA } \\
\text { SYMBOLS }\end{array}$ & $\begin{array}{c}\text { ACCOUNT/FAN PAGE/GROUP } \\
\text { ACCOUNT \& MOST SUPPORTERS }\end{array}$ \\
\hline Facebook & $\begin{array}{l}\text { - Aksi Bela Islam [Islamic } \\
\text { Defense Action] } \\
\text { - \#belaquran }\end{array}$ & $\begin{array}{l}\text { Aksi Bela Islam (@aksibelaislamalquran) } \\
\text { - } 21.292 \text { people like } \\
\text { - } 21.738 \text { people follow }\end{array}$ \\
\hline Twitter & $\begin{array}{l}\text { [\#defendquran] } \\
\text { - \#belaulama }\end{array}$ & $\begin{array}{l}\text { Aksi212 (@RemajaIslam212) } \\
\text {-3481 followers }\end{array}$ \\
\hline Instagram & $\begin{array}{l}\text { [\#defendulama] } \\
\text { - \#spirit212 [\#212spirit] } \\
\text { - \#aksibelaislam } \\
\text { [\#islamicdefenseaction] }\end{array}$ & $\begin{array}{l}\text { - \#aksibelaislam (121.069 post) } \\
\text { - Aksi Bela Islam (bela.islam). } 15300 \\
\text { followers. } \\
\text { - Cyber Muslim Community } \\
\text { (cybermuslimcommunity). } 48300 \\
\text { followers. } 619 \text { posts } \\
\text { - Cyber Army Muslim (cyber.army. } \\
\text { muslim) } 18200 \text { followers, } 1225 \text { posts } \\
\text { - \#2019gantipresiden } \\
\text { (muslimcyberarmy_id2) } 12400 \\
\text { followers, } 559 \text { posts }\end{array}$ \\
\hline
\end{tabular}

The Islamic Defense Action has not only cultivated Islamic messages, jargon and propaganda in the social media; it has also spawned actors who have the role in spreading Islamic propaganda in the social media world. In fact, the Islamic Defense Action cannot be separated from the old actors who often roll out the discourses of post-Islamism in Indonesia that is Habib Rizieq Shihab.32 At the beginning of the post-Reform decade, Habib Rizieq often threw a harsh response to democracy as a modern political system. He argued that Islam prioritizes deliberation,

32 Arie Setyaningrum Pamungkas dan Gita Octaviani, "Aksi Bela Islam dan Ruang Publik Muslim: Dari Representasi Daring ke Komunitas Luring," Jurnal Pemikiran Sosiologi 4, No. 2 (Agustus, 2017), 68. 
and deliberations are very different from the meaning of democracy. Democracy puts forward the most votes or votes, while deliberations put forward the results of an agreement guided by Islamic values. At one time, he mentioned that democracy is more dangerous than pigs, and democracy is the same as pigs that can be consumed only when in a very forced state. ${ }^{33}$ As the ongoing process of democratization in Indonesia continues, Habib Rizieq is now using the tools of democracy to launch Islamic propaganda in order to influence political policies that are considered to be detrimental to Muslims. This change of perspective towards democracy is one of the indications of a change in Islamism's reasoning towards post-Islamism. The Islamic Defense Action can be regarded as a manifestation of post-Islamism in the Reformation era.

Besides Rizieq, the growing actor in Aksi Bela Islam is Ustadz Bachtiar Nasir. This Islamic figure is an alumnus of Gontor, one of the famous modern Islamic boarding schools (pesantren) located in Ponorogo district of East Java province. He then pursued his higher education at the Islamic University of Madinah, Saudi Arabia. Bachtiar Nasir's figure as an activist has skyrocketed since the Islamic Defense Action II on November 4, 2016 where he was asked to become the chairman of the National Movement of Fatwa Guard for the Indonesian Council of Ulama's fatwa (GNPF-MUI). Although his track record was as administrators of the Muhammadiyah Central Board, the Islamic Defense Action did not present Nasir as a picture of Muhammadiyah's figure. ${ }^{34}$ In addition to Nasir, another figure who appears during the Islamic Defense Action was Ustadz Abdul Somad. Abdul Somad is basically not a figure directly involved in the voluminous

33 "Habib Rizieq: Demokrasi Lebih Bahaya Dari Babi," Arrahmah.Com, n.d., accessed June 28, 2018, https://www.arrahmah.com/2013/04/02/habib-rizieq-demokrasi-lebihbahaya-dari-babi/; "Habib Rizieq: Perbedaan Islam Dan Demokrasi," accessed June 28, 2018, https://www.youtube.com/watch?v=OkhNjm8ur7I.

34 Institute for Policy Analysis of Conflict, "After Ahok: The Islamist Agenda in Indonesia," IPAC Report No. 44 (6 April 2018), 4-8. 
Islamic Defense Action. However, the momentum of the Islamic Defense Action coincided with the viral da ' wah videos of Ustadz Abdul Somad in late 2016. Some of his video clips are often cited for propaganda support for the jargon of the Islamic Defense Action movement such as the Bela al-Quran Action, spirit 212, and others.

Ustadz Bachtiar Nasir and UstadzAbdul Somad are two figures who are currently often featured in the internet world. Digital record of these two figures is very easy to get. Through the Google search engine, the keyword "Ustadz Bachtiar Nasir" will generate approximately 727,000 relevant topics from various websites. Keywords for "Ustadz Abdul Somad" generates 17 million more topics. In terms of quantity, search results online of these two figures actually beat the mainstream Islamic organizations figures like Said Aqil Siradz, Mustofa Bisri, Haidar Nashir, Syafi' i Ma'arif which display results of about 300,000 related topics. On the website of Youtube, there are about 780,000 videos featuring Ustadz Abdul Somad' figure. ${ }^{35}$

Again responding to a previously asked question about whether a large quantity of occurrences in various online media can make the figure an authoritative source for shaping the religiosity of Indonesian community and spreading massive religious propaganda? Currently, the authority of institutions that play a role in shaping the attitude of the Islamic community of Indonesia is not yet able to move from Islamic mass organizations and various traditional religious institutions that have been present since the era of independence and even earlier. Muhammadiyah and Nahdhatul Ulama have many grassroots from various educational institutions ranging from Islamic boarding schools and high schools to university. These two mainstream organizations in Indonesia are still influencing the religious character (Islam) in Indonesia with the

\footnotetext{
${ }^{35}$ According to search results in google search engine in 25 $5^{\text {th }}$ of April 2019
} 
spread of its members in various state institutions that can influence government policy in Indonesia. However, this Islamic clicktivism has become a growing trend in the grassroots community as a new social movement and bringing in new actors. The blast of Islamic clicktivism is the mouthpiece of propaganda of new Islamic figures in the digital age and enables the future trajectory for the birth of new Islamic religious character in Indonesia in the future.

\section{Conclusion: The Future of Aksi Bela Islam}

The Islamic Defense Action has left traces of online activism on the Islamic social movement in Indonesia. Within the framework of the new social movement, the existence of Islamic Defense Action can clarify some matters relating to socio-political phenomena. First, the Islamic Defense Action is one of the consequences of the post-democratization of the society polarization, whereby the struggle for public space is getting bigger and free. This polarization leads to the disintegration of the mainstream concentration of authoritative Islamic religious movements; Muhammadiyah and Nahdhatul Ulama in shaping the religious pattern for the majority of Muslims in Indonesia. One of the signs of the weakening of Muhammadiyah and NU in establishing itself as an authoritative Islamic mass is by the emergence of new actors in the Islamic Defense Action in volumes. These actors appear by not carrying flags of mainstream Islamic Organizations. The arising some new actors in / and after Islamic defense action describes the growing trend of flourishing new authoritative figure who believed to be the source of propaganda in terms of Islam and Indonesian-ness. Secondly, the Islams defense action strengthens the previous scholars' thesis on Dynamic Interplay beetween offline and online activism. The sympathizers of the Islam defense action use clicktivism as a social movement's success strategy. Islamic 
clicktivism is used for an action that can be measured its success in terms of virtual (online) and real (offline). The offline social movement will be led to the assumption that Islamic social movements will potentially succeed if it brings up national interest issues and the diverse elements of society that participate in an action. Ultimately, the Islamic Defense Action is a new trend that is a consequence of dynamic contestation between Islamic identity and modern democratic values that seem vis a vis in the public sphere. This post-democratization religious contestation in Indonesia also raises a new religious authority that plays the role of Islamic social movements outside mainstream Islamic organizations in Indonesia. The new actors who emerged after the Islamic Defense Action became a source of Islamic propaganda in which their actions, direction and speech were considered the authority representing Islam entirely. The attitude of the new actors is then disseminated with cliktifism as a strategic step for the success of activism in the online world and offline. This Islamic activism will always color the contestation of identity in post-Islamism era, especially in the political moments in Indonesia.

\section{Bibliography}

Ahyar, Muzayyin, "Islamic Clicktivism: Internet, Democracy and Contemporary Islamist Activism in Surakarta", Studia Islamika vol 24, no. 3 (December 31, 2017): 435-468.

Azra, Azyumardi, Kees van Dijk, and Nico J. G. Kaptein. Varieties of Religious Authority: Changes and Challenges in 20th Century Indonesian Islam. Institute of Southeast Asian Studies, 2010.

Barber, Benjamin. Jihad vs. McWorld: Terrorism's Challenge to Democracy.

New York: Random House Publishing Group, 2010.

Bayat, Asef. Post-Islamism: The Changing Faces of Political Islam. USA: Oxford University Press, 2013.

Bernays, Edward. Propaganda. New York: Ig Publishing 2005. 
Burdah, Ibnu, "Morocco Protest Movements in the Post-Constitutional Reform", Indonesian Journal of Islam and Muslim Societies 7, no. 2 (December 1, 2017): 201-219.

Burhani, Ahmad Najib, "Aksi Bela Islam: Konservatisme dan Fragmentasi Otoritas Keagamaan,” Maarif 11, No. 2 (December 2016): 15-29. Cheater, Angela. The Anthropology of Power. London: Routledge, 2003. Cunningham, Stanley B. The Idea of Propaganda: A Reconstruction. USA: Greenwood Publishing Group, 2002.

Eisinger, Peter K., "The Conditions of Protest Behavior in American Cities', The American Political Science Review, Vol. 67. No.1 (1972): 108-172.

Esposito, John L., and John Obert Voll. Islam and Democracy. USA: Oxford University Press, 1996.

Fealy, Greg. "Bigger than Ahok: Explaining the 2 December Mass Rally." Indonesia at Melbourne. Last modified December 7, 2016. Accessed March 29, 2017. http://indonesiaatmelbourne.unimelb.edu.au/ bigger-than-ahok-explaining-jakartas-2-december-mass-rally/.

Herdiansah, Ari Ganjar, et.al., "The Islam Defence Action: A Challenge of Islamic Movement to Democratic Transition in the Post 2014 Indonesia," Wacana, Vol. 20, No. 2 (2017): 57-67.

Institute for Policy Analysis of Conflict, "After Ahok: The Islamist Agenda in Indonesia," IPAC Report No. 44 (6 April 2018): 1-28. Iqbal, Asep Muhammad, and Zulkifli Zulkifli, "Islamic Fundamentalism, Nation-State and Global Citizenship: The Case of Hizb Ut-Tahrir", Indonesian Journal of Islam and Muslim Societies, Vol. 6, no. 1 (June 1, 2016): 35-61.

Johnston, Hank. What Is a Social Movement? UK: John Wiley \& Sons, 2014.

Juergensmeyer, Mark. The New Cold War? Religious Nationalism Confronts the Secular State. California; University of California Press, 1993.

Keane, John. Global Civil Society? UK: Cambridge University Press, 2003. Lim, Merlyna. "Freedom to Hate: Social Media, Algorithmic Enclaves, and the Rise of Tribal Nationalism in Indonesia." Critical Asian Studies 49, no. 3 (July 3, 2017): 411-427. 
Lim, Merlyna. "@rchipelago Online: The Internet and Political Activism in Indonesia." Ph,D Thesis Twente, 2005.

Lim, Merlyna, "Many Clicks but Little Sticks: Social Media Activism in Indonesia," Journal of Contemporary Asia, Vol. 43, No. 4 (2013): 636657.

Mahdiduri, Mahdiduri. Ubrug; Tontonan dan Tuntunan. Dinas Pendidikan Propinsi Banten \& Lembaga Keilmuan dan Kebudayaan Nimus Institut, 2010.

O'Shaughnessy, Nicholas J. Politics and Propaganda: Weapons of Mass Seduction. UK: Manchester University Press, 2004.

Pamungkas, Arie Setyaningrum and Octaviani, Gita, "Aksi Bela Islam dan Ruang Publik Muslim: Dari Representasi Daring ke Komunitas Luring," Jurnal Pemikiran Sosiologi, Vol. 4, No. 2 (Agustus, 2017): $65-$ 87.

Rheingold, Howard. The Virtual Community: Homesteading on the Electronic Frontier. London: MIT Press, 2000.

Tarrow, Sidney. Power in Movement: Social Movements and Contentious Politics. New York: Cambridge University Press, 1998.

Van Laer, Jeroen, and Peter Van Aelst, "Internet and Social Movement Action Repertoires: Opportunities and Limitations", Information, Communication $\mathcal{E}$ Society Vol.13, No. 8 (December 2010): 1146-1171.

Weber, Max. On Charisma and Institution Building. Chicago: University of Chicago Press, 1968.

Weber, Max. The Protestant Ethic and the Spirit of Capitalism. New York: Scribner, 1958.

White, Micah. The End of Protest: A New Playbook for Revolution. Canada: Knopf Canada, 2016.

Widiyanto, Asfa. Religious Authority and the Prospects for Religious Pluralism in Indonesia: The Role of Traditionalist Muslim Scholars. Berlin: LIT Verlag Münster, 2016.

"Digital in 2018: World's Internet Users Pass the 4 Billion Mark - We Are Social UK." Accessed June 22, 2018. https://wearesocial.com/uk/ blog/2018/01/global-digital-report-2018. 
Aksi Bela Islam: islamic clicktivism and the new authority of religious... (Muzayyin Ahyar, Alfitri)

"Habib Rizieq: Demokrasi Lebih Bahaya Dari Babi." Arrahmah.Com, n.d. Accessed June 28, 2018. https://www.arrahmah.com/2013/04/02/ habib-rizieq-demokrasi-lebih-bahaya-dari-babi/.

"Habib Rizieq: Perbedaan Islam Dan Demokrasi." Accessed June 28, 2018. https://www.youtube.com/watch?v=OkhNjm8ur7I. 
